\title{
Peningkatan Hasil Belajar IPS Peserta Didik Tentang Perbedaan Iklim Melalui Model Pembelajaran Kooperatif Tipe Gallery Walk di Kelas IV SDN 015/X Kuala Lagan Semester Ganjil Tahun Ajaran 2021/2022
}

\author{
Ramli \\ SDN 015/X Kuala Lagan \\ Jl. Kampng Laut.Parit, Kuala Lagan, Jambi, Indonesia \\ ramli@gmail.com
}

\begin{abstract}
This study aims to describe and obtain information on improving social studies learning outcomes through the Gallery Walk type cooperative learning model. This research is classroom action research consisting of two cycles, each cycle consisting of two meetings. Each meeting consists of four stages, namely planning, implementation, observation, and reflection. The subjects of this study were fourth grade students at SDN 015/X Kuala Lagan, totaling 14 people. This research was conducted in the odd semester of the 2021/2022 academic year. Data collection techniques using tests, observations, and documentation. Data were analyzed using percentages and data reduction. The results showed that the Gallery Walk learning model could improve social studies learning outcomes for fourth grade students at SDN 015/X Kuala Lagan by giving praise.
\end{abstract}

Keywords: Social Studies learning outcomes, Gallery Walk

\begin{abstract}
Abstrak
Penelitian ini bertujuan untuk mendeskripsikan dan mendapatkan informasi peningkatan hasil belajar IPS melalui model pembelajaran Kooperatif Tipe Gallery Walk. Penelitian ini merupakan penelitian tindakan kelas yang terdiri dari dua siklus masing-masing siklus terdiri dari dua kali pertemuan. Masing-masing petemuan terdiri dari empat tahapan yaitu perencanaan, pelaksanaan, observasi dan refleksi. Subjek penelitian ini adalah peserta didik kelas IV SDN 015/X Kuala Lagan yang berjumlah sebanyak 14 orang. Penelitian ini dilaksanakan pada semseter ganjil tahun ajaran 2021/2022. Teknik pengumpulan data menggunakan tes, observasi, dan dokumentasi. Data dianalisis menggunakan persentase dan reduksi data. Hasil penelitian menunjukkan bahwa melalui model pembelajaran Gallery Walk dapat meningkatkan hasil belajar IPS peserta didik kelas IV SDN 015/X Kuala Lagan dengan tindakan pemberian pujian.
\end{abstract}

Kata kunci: Hasil Belajar IPS, Gallery Walk

Copyright (c) 2022 Ramli

Corresponding author: Ramli

Email Address: ramli@gmail.com (Jl. Kampung Laut, Kuala Lagan, Jambi)

Received 10 January 2022, Accepted 20 January 2022, Published 31 January 2022

\section{PENDAHULUAN}

Berdasarkan Undang-Undang Guru dan Dosen pasal 1 ayat (1) (dalam Iskandar, 2009: 1) menyebutkan guru adalah pendidik profesional dengan tugas utama mendidik, mengajar, membimbing, mengarahkan, melatih, menilai dan mengevaluasi peserta didik pada pendidikan anak usia dini jalur pendidikan formal, pendidikan dasar dan pendidikan menengah. Pelaksanaan peran tersebut menjadikan tugas dan tanggung jawab guru menjadi berat. Ini mengakibatkan guru mempunyai peran ganda di sekolah. Selain mengajar, guru harus memberikan tuntunan, bimbingan, asuhan, latihan dan teladan kepada peserta didik serta melaksanakan menilai dan mengevaluasi peserta didik dalam kelas. 
Tujuan umum pendidikan untuk membentuk peserta didik yang mandiri dalam konteks kehidupan pribadinya, bermasyarakat, berbangsa dan bernegara, serta sebagai makhluk Tuhan beragama. Selain itu, memberikan bekal kepada peserta didik supaya mampu hidup layak dan dapat hidup bermasyarakat dengan baik. Melalui pengetahuan, keterampilan, dan kreatifitas yang dimiliki, mereka mampu mencari nafkah dengan baik sesuai dengan tingkatannya dan dapat melanjutkan studi ke jenjang yang lebih tinggi. sekolah merupakan ujung tombak pencapaian tujuan pendidikan. Guru sebagai tenaga pendidik mempunyai peran penting dalam pelaksanaan pendidikan di sekolah.

Guru sebagai komponen penting dari tenaga kependidikan memiliki tugas untuk melaksanakan proses pembelajaran, diantaranya melakukan pengelolaan belajar. Sehubungan dengan hal ini, peran guru dalam pengelolaan belajar sangat menentukan pencapaian tujuan pembelajaran, karena guru adalah pemimpin di dalam kelas. Oleh karena itu, guru yang lebih tahu dan sangat menentukan bagaimana proses pembelajaran berlangsung di dalam kelas.

Sebagai pengelola pembelajaran, guru harus merencanakan, melaksanakan dan mengevaluasi kegiatan pembelajaran. Pada kegiatan perencanaan, guru merumuskan tujuan khusus yang akan dicapai dalam pembelajaran serta merencanakan materi yang akan dipelajari untuk mencapai tujuan. Dalam merencanakan materi yang akan dipelajari, guru tidak hanya memikirkan materi bagian demi bagian, tetapi juga memikirkan keterkaitan materi tersebut satu sama lainnya, sehingga peserta didik dapat mempelajari materi secara utuh. Supaya materi pembelajaran dapat diterima dengan baik, maka guru harus memperhatikan penggunaan strategi, metode, dan media yang tepat.

Menurut Yamin (2002:10), guru yang salah satu perannya sebagai fasilitator memiliki peran memfasilitasi peserta didik untuk belajar secara maksimal dengan mempergunakan berbagai strategi, metode, media dan sumber belajar. Dalam proses pembelajaran, peserta didik sebagai titik sentral belajar. Peserta didik yang lebih aktif mencari dan memecahkan permasalahan belajar dan guru membantu kesulitan peserta didik-peserta didik yang mendapat kendala, baik kesulitan dalam memahami maupun memecahkan persoalan.

Penggunaan metode yang tepat akan membantu guru dalam penyajian materi dan membantu peserta didik untuk memahami materi. Dalam pemilihan materi, guru harus mempertimbangkan sifat materi, karena satu metode belum tentu tepat untuk materi yang lain. Seringkali guru dalam memilih metode cenderung pada yang biasa mereka lakukan, seperti metode ceramah. Menurut para guru, metode ceramah merupakan metode yang mudah dilaksanakan dan tidak memerlukan persiapan yang rumit. Dalam pelaksanaan metode ini, guru hanya memberi informasi (proses satu arah) tanpa ada umpan balik, maka lingkungan dan proses pembelajaran hanyalah terpusat pada guru (teacher centred), sementara peserta didik tidak dilibatkan secara aktif dalam pembelajaran. Hal ini akan mengakibatkan peserta didik pasif selama pembelajaran dan merasa jenuh sehingga tidak semangat dalam proses pembelajaran. Pembelajaran yang membuat peserta didik pasif akan mengakibatkan peserta didik hanya mampu mengulang materi yang disampaikan guru, dan jika ada pertanyaan yang 
bersifat aplikasi, peserta didik akan sulit menjawabnya. Jika hal ini terus berlangsung, akan menyebabkan hasil belajar peserta didik rendah.

Hasil belajar yang harus dimiliki peserta didik setelah pembelajaran berlangsung mencakup tiga ranah, yaitu kognitif, afektif dan psikomotor. Berdasarkan kenyataan di lapangan, aktivitas dan hasil belajar yang dimiliki peserta didik, khususnya pada mata pelajaran IPS lebih banyak pada ranah kognitif masih belum cukup optimal karena pada umumnya peserta didik masih menghafal dan kurang memahami materi yang telah dipelajari tanpa mampu mengembangkan dan mengaitkan materi-materi yang telah dipelajari.

Berdasarkan observasi awal diketahui peserta didik cenderung kurang menyukai pelajaran IPS sehingga hasil belajar peserta didik cenderung rendah. Hal ini dapat dilihat dari hasil observasi untuk hasil ulangan harian semester ganjil kelas IV di SDN 015/X Kuala Lagan tahun ajaran 2021/2022 dimana masih banyaknya peserta didik yang belum mencapai kriteria ketuntasan yang ditetapkan. Keadaan pembelajaran seperti di atas akan memberikan efek yang buruk pada hasil belajar peserta didik khususnya dan tidak tercapainya tujuan pembelajaran. Ini terlihat dari hasil belajar yang dimiliki oleh kelas IV SDN 015/X Kuala Lagan, dimana kelas ini belum mampu mencapai Kriteria Ketuntasan Minimum untuk nilai rata-rata kelas yang hanya sebesar 20\%. Berdasarkan masalah di atas maka salah satu upaya yang dapat dilakukan untuk meningkatkan hasil belajar peserta didik adalah menggunakan strategi pembelajaran.

Menurut Sanjaya (2012:128) Strategi pembelajaran merupakan suatu yang diterapkan guru akan tergantung pada pendekatan yang digunakan, sedangkan bagimana menjalankan strategi itu dapat diterapkan berbagai model pembelajaran. Pemilihan model pembelajaran disesuaikan dengan tujuan kurikulum dan potensi peserta didik merupakan kemampuaan dan keterampilan dasar yang harus dimiliki oleh seorang guru karena metode dan model pembelajaran yang digunakan oleh guru berpengaruh terhadap keberhasilan dan hasil belajar peserta didik (Kosasi, 1996:2). Salah satu model pembelajaran kooperatif yang cocok untuk matapelajaran IPS ialah Gallery Walk. Gallery Walk menurut Silberman (2005: 274) merupakan suatu cara untuk menilai atau mengingat dan merayakan apa yang telah (peserta didik) pelajari setelah rangkaian pelajaran studi. maka tujuan yang ingin dicapai dari penelitian ini yaitu, Peningkatkan hasil belajar IPS peserta didik melalui model pembelajaran Gallery Walk di kelas IV SDN 015/X Kuala Lagan.

Slameto (2010:2) mengungkapkan belajar ialah suatu proses usaha yang dilakukan seseorang untuk memperoleh suatu perubahan tingkah laku yang baru secara keseluruhan, sebagai hasil pengalamannya sendiri dalam interaksi dengan lingkungannya. Belajar secara umum, dapat diartikan sebagai proses perubahan prilaku akibat interaksi individu dengan lingkungannya. Sedangkan menurut Winkel (dalam Riyanto, 2012:5) belajar adalah suatu aktivitas mental/psikis yang berlangsung dalam interaksi aktif dengan lingkungan, yang menghasilkan perubahan-perubahan dalam pengetahuan-pemahaman, ketrampilan dan nilai sikap. Perubahan itu bersifat secara relatif konstan dan berbekas. 
Menurut Gagne belajar merupakan kecendrungan perubahan pada diri manusia yang dapat diperhatikan selama proses pertumbuhan. Hal ini dijelaskan kembali oleh gagne (dalam Riyanto, 2012:5) bahwa belajar merupakan suatu peristiwa yang terjadi di dalam kondisi-kondisi tertentu yang dapat diamati, diubah dan di kontrol. Sedangkan Suprijono (2012:4) mengemukakan hasil belajar adalah perubahan prilaku secara keselurahan bukan hanya salah satu aspek potensi kemanusiaan saja. Berdasarkan uraian di atas dapat disimpulkan bahwa hasil belajar adalah prestasi belajar yang dicapai peserta didik dalam kegiatan belajar mengajar. Hasil belajar yang dicapai hendaknya perubahan dan pembentukan tingkah laku seseorang, seperti perkembangan kognitif, pola-pola perbuatan, nilai-nilai, sikap dan keterampilan.

Gagne (dalam Pribadi, 2011:9) mendefenisikan pembelajaran sebagai "a set of events embedded is purposeful activities that facilitate learning". Pembelajaran adalah serangkaian aktivitas yang disengaja diciptakan dengan maksud untuk memudahkan terjadinya pembelajaran. Sedangkan pembelajaran menurut Degeng (dalam Wena, 2010:2) pembelajaran berarti upaya membelajarkan peserta didik.

Menurut Sapriya (2009: 19) Pelajaran "Ilmu Pengetahuan Sosial", disingkat IPS, merupakan nama mata pelajaran di tingkat sekolah dasar dan menengah atau nama program studi di perguruan tinggi identik dengan istilah "social studies". Pengertian IPS di sekolah dasar merupakan nama mata pelajaran yang berdiri sendiri sebagai integrasi dari sejumlah konsep disiplin ilmu sosial, humaniora, sains bahkan berbagai isu dan masalah sosial kehidupan Sapriya (2009: 20). Materi IPS untuk jenjang sekolah dasar tidak terlihat aspek disiplin ilmu karena lebih dipentingkan adalah dimensi pedagogik dan psikologis serta karakteristik kemampuan berpikir peserta didik yang bersifat holistik (Sapriya, 2009: 20). Pengertian IPS adalah suatu bahan kajian terpadu yang merupakan penyederhanaan, adaptasi, seleksi dan modifikasi diorganisasikan dari konsep-konsep ketrampilan-ketrampilan Sejarah, Geografi, Sosiologi, Antropologi, dan Ekonomi (Puskur, 2001: 9). Fakih Samlawi \& Bunyamin Maftuh (1999: 1) menyatakan bahwa IPS merupakan mata pelajaran yang memadukan konsep-konsep dasar dari berbagai ilmu sosial disusun melalui pendidikan dan psikologis serta kelayakan dan kebermaknaannya bagi peserta didik dan kehidupannya.

Adanya mata pelajaran IPS di Sekolah Dasar para peserta didik diharapkan dapat memiliki pengetahuan dan wawasan tentang konsep-konsep dasar ilmu sosial dan humaniora, memiliki kepekaan dan kesadaran terhadap masalah sosial di lingkungannya, serta memiliki ketrampilan mengkaji dan memecahkan masalah- masalah sosial tersebut. Pembelajaran IPS lebih menekankan pada aspek "pendidikan" dari pada transfer konsep karena dalam pembelajaran IPS peserta didik diharapkan memperoleh pemahaman terhadap sejumlah konsep dan mengembangkan serta melatih sikap, nilai, moral dan ketrampilannya berdasarkan konsep yang telah dimilikinya.

Secara etimologi, Gallery Walk terdiri dari dua kata yaitu Gallery dan walk. Gallery adalah pameran. Pameran merupakan kegiatan untuk memperkenalkan produk, karya atau gagasan kepada khalayak ramai. Misalnya pameran buku, tulisan, lukisan dan sebagainya. Sedangkan walk artinya 
berjalan atau melangkah (Ismail, 2008:89). Sedangkan Gallery Walk menurut Silberman (2005: 274) merupakan suatu cara untuk menilai atau mengingat dan merayakan apa yang telah (peserta didik) pelajari setelah rangkaian pelajaran studi.

Dari uraian di atas dapat disimpulkan bahwa GW merupakan suatu model pembelajaran yang mampu meningkatkan kemampuan peserta didik untuk menemukan pengetahuan baru dan dapat mempermudah daya ingat, karena sesuatu yang ditemukan itu secara langsung. Gallery Walk termasuk dalam model pembelajaran aktif (Active learning strategy), pembelajaran aktif (active learning) dimaksudkan untuk mengoptimalkan penggunaan semua potensi yang dimiliki oleh anak didik, sehingga semua anak didik dapat mencapai hasil belajar yang memuaskan sesuai dengan karakteristik pribadi yang mereka miliki.

\section{METODE}

\section{Setting Penelitian}

Jenis penelitian ini adalah penelitian tindakan kelas. Penelitian ini dilaksanakan di SDN 015/X Kuala Lagan pada semester ganjil, tahun ajaran 2021/2022. Subjek dalam penelitian ini adalah siswa IV dengan jumlah peserta didik 14 orang. Prosedur penelitian ini meliputi perencanaan, pelaksanaan, pengamatan, dan refleksi. Penelitian ini dilaksanakan dalam dua siklus, masing-masing siklus terdiri dari dua kali pertemuan. Teknik yang digunakan dalam pengumpulan data adalah observasi, tes, catatan lapangan dan dokumentasi. Data dianalisis melalui persentase dan reduksi data.

\section{HASIL DAN DISKUSI}

\section{Siklus I}

1. Perencanaan

Pada tahap ini peneliti mempersiapkan perangkat pembelajaran yang terdiri dari rencana pelajaran, Silabus, LKS 1, media pembelajran, soal tes formatif 1, lembar observasi, dan alat-alat pengajaran yang mendukung.

2. Pelaksanaan

Pertemuan pertama siklus I dilaksanakan pada hari Kamis tanggal 02 September 2021 pada jam 08.05-09.45 yang membahas tema Peduli terhadap makhluk hidup. Pada pertemuan pertama siklus I ini terdiri dari kegiatan pendahuluan, inti, dan penutup. Pada kegiatan pendahuluan ini hal-hal yang dilakukan adalah kelas dibuka dengan salam, menanyakan kabar, dan guru mengecek kehadiran peserta didik. Peserta didik dan guru berdoa yang dipimpin oleh salah satu peserta didik. Peserta didik bersama guru mengkondisikan kelas kemudian menyanyikan lagu Indonesia raya. Setelah itu guru memberikan penjelasan tentang sikap disiplin dan tanggung jawab yang akan dikembangkan dalam pembelajaran.

Pada kegiatan inti ini dilakukan dengan beberapa tahap yaitu peserta dibagi ke dalam kelompok-kelompok (4 kelompok) yang terdiri atas 4 anggota, salah satu anggota berisikan 3 orang. 
Kemudian setiap kelompok diberi kertas plano atau flip cart. Kemudian setiap kelompok ditentukan topik atau tema pembelajaran yang akan dibahasnya. Tema yang akan dibagikan ialah seputar bentang alam Indonesia yaitu yang meliputi pantai, dataran rendah, dan dataran tinggi. Setiap kelompok mendiskusikan apa yang ia ambil dari materi tersebut. Hasil kerja kelompok ditempel didinding. Masing-masing kelompok berputar mengamati hasil kerja kelompok lain dan menempeli dinding dengan daftar-daftar komentar. Salah satu wakil kelompok menjelaskan setiap apa yang ditanyakan oleh kelompok lain. Kelompok yang bertugas memberikan penjelasan pada pertemuan ini ialah oleh kelompok 1 dan 2. Lalu peserta didik bersama guru melakukan koreksi secara bersama-sama. Lalu guru bersama peserta didik melakukan klarifikasi dan penyimpulan.

Pada kegiatan penutup ini, peserta didik bersama guru melakukan refleksi terhadap pembelajaran yang sudah berlangsung. Kemudian guru bersama peserta didik menyimpulkan hasil pembelajaran. Lalu peserta didik menyimak penjelasan guru tentang aktivitas pembelajaran pada pertemuan berikutnya. Tidak lupa pula guru memberikan motivasi tentang pentingnya sikap disiplin dan tanggung jawab. Setelah itu peserta didik diinstruksikan untuk menjaga kebersihan kelas. Dan terakhir kelas ditutup dengan do'a bersama yang dipimpin oleh salah satu peserta didik.

Pertemuan kedua siklus I dilaksanakan pada hari Jum'at tanggal 3 September 2021 pada jam 08.05-09.45 yang membahas materi tentang bentang alam Indonesia dan perbedaan daratan tinggi, dataran rendah, dan pantai. Sama halnya pada pertemuan kedua siklus I ini terdiri dari kegiatan pendahuluan, inti, dan penutup.

Pada kegiatan pendahuluan ini hal-hal yang dilakukan adalah kelas dibuka dengan salam, menanyakan kabar, dan guru mengecek kehadiran peserta didik. Peserta didik dan guru berdoa yang dipimpin oleh salah satu peserta didik. Peserta didik bersama guru mengkondisikan kelas kemudian menyanyikan lagu Indonesia raya. Setelah itu guru memberikan penjelasan tentang sikap disiplin dan tanggung jawab yang akan dikembangkan dalam pembelajaran. Pada awal pembelajaran guru mengingatkan kepada peserta didik bahwasanya di akhir pelajaran akan di adakan ulangan harian. Pada kegiatan ini dilakukan dengan beberapa tahap yaitu peserta dibagi ke dalam kelompokkelompok (4 kelompok) yang terdiri atas 4 anggota, salah satu anggota berisikan 3 orang. Kemudian setiap kelompok diberi kertas plano atau flip cart. Kemudian setiap kelompok ditentukan topik atau tema pembelajaran yang akan dibahasnya.

Tema yang akan dibagikan ialah seputar bentang alam Indonesia yaitu yang meliputi pantai, dataran rendah, dan dataran tinggi. Setiap kelompok mendiskusikan apa yang ia ambil dari materi tersebut. Hasil kerja kelompok ditempel didinding. Masing-masing kelompok berputar mengamati hasil kerja kelompok lain dan menempeli dinding dengan daftar-daftar komentar. Salah satu wakil kelompok menjelaskan setiap apa yang ditanyakan oleh kelompok lain. Kelompok yang bertugas memberikan penjelasan pada pertemuan ini ialah oleh kelompok 3 dan 4. Lalu peserta didik bersama guru melakukan koreksi secara bersama-sama. Lalu guru bersama peserta didik melakukan klarifikasi dan penyimpulan. 
Pada kegiatan penutup ini, peserta didik bersama guru melakukan refleksi terhadap pembelajaran yang sudah berlangsung. Kemudian guru bersama peserta didik menyimpulkan hasil pembelajaran. Lalu peserta didik menyimak penjelasan guru tentang aktivitas pembelajaran pada pertemuan berikutnya. Tidak lupa pula guru memberikan motivasi tentang pentingnya sikap disiplin dan tanggung jawab. Setelah itu peserta didik diinstruksikan untuk menjaga kebersihan kelas. Dan terakhir kelas ditutup dengan do'a bersama yang dipimpin oleh salah satu peserta didik.

3. Observasi

Pada akhir proses belajar mengajar peserta didik diberi tes formatif I dengan tujuan untuk mengetahui tingkat keberhasilan peserta didik dalam proses belajar mengajar yang telah dilakukan. Adapun data hasil penelitian pada siklus I adalah sebagai berikut:

Tabel 1. Rekapitulasi Ketuntasan Belajar Peserta didik Siklus I

\begin{tabular}{|c|c|c|}
\hline No & Uraian & Hasil \\
\hline 1 & Jumlah Nilai & 920 \\
\hline 2 & Rata-rata Nilai & 65.71 \\
\hline 3 & Peserta didik Tuntas & 8 \\
\hline 4 & Peserta didik Tidak Tuntas & 6 \\
\hline 5 & Persentase Peserta didik Tuntas & $57 \%$ \\
\hline 6 & Persentase Peserta didik Tidak Tuntas & $43 \%$ \\
\hline
\end{tabular}

Dari tabel di atas dapat dijelaskan bahwa setelah menerapkan model pembelajaran Gallery Walk pada siklus I ini di peroleh rata - rata hasil belajar peserta didik yaitu 65,71 dengan jumlah peserta didik yang tuntas sebesar $57 \%$ ( 8 orang peserta didik) dan selebihnya $43 \%$ belum tuntas (6 orang peserta didik). Dengan demikian, berdasarkan tabel hasil belajar peserta didik di atas serta penjelasannya dapat disimpulkan bahwa masih banyak peserta didik yang belum tuntas dalam belajar. Hasil tersebut lebih kecil dari presentase ketuntasan klasikal dalam proses pembelajaran IPS yang dikehendaki sebesar $80 \%$.

\section{Refleksi}

Refleksi dilaksanakan pada hari Senin, tanggal 6 september 2021. Berikut ini adalah hasil pengamatan oleh kolaborator Zulfahmi S. Ag. terhadap proses pembelajaran dengan menggunakan model Gallery Walk. Berdasarkan hasil pengamatan kolaborator terhadap pelaksanaan proses pembelajaran melalui model Gallery Walk maka untuk mencapai tujuan yang diharapkan dalam penelitian ini dapat dikemukakan hal-hal sebagai berikut: 1) Guru belum maksimal melaksanakan proses pembelajaran dengan menggunakan model pembelajaran Gallery Walk yaitu guru masih mendominasi waktu pembelajaran. Hal ini disebabkan oleh peserta didik banyak diam. 2) Peserta didik belum paham tentang model pembelajaran yang dilakukan oleh guru. 3) Pemahaman peserta didik terhadap materi masih kurang. 4) Pernyataan peserta didik masih mengambang karena tidak menguasai materi. 5) Kelemahan peserta didik dapat terlihat dari ketidakberaniannya menanggapi 
pernyataan temannya. Berdasarkan kendala yang masih di temui di atas maka penelitian ini dilanjutkan ke siklus selanjutnya dengan tindakan pemberian reward/hadiah.

\section{Siklus II}

a. Perencanaan

Pada tahap ini peneliti mempersiapkan perangkat pembelajaran yang terdiri dari rencana pelajaran, silabus, LKS 2, soal tes formatif II, menyiapkan media pembelajaran, dan alat-alat pengajaran yang mendukung kemudian menyiapkan reward/hadiah.

b. Pelaksanaan

Pertemuan pertama siklus I dilaksanakan pada hari senin tanggal 4 oktober 2021 pada jam 9.45-10.55 yang membahas materi tentang perbedaan jensis tanaman berdasarkan karakteristik bentang alam. Pada pertemuan pertama siklus II ini tidak jauh berbeda dengan siklus pertama tetapi guru memberitahukan kepada peserta didik bahwa yang mendapat nilai tertinggi akan diberi reward/hadiah. Pertemuan pertama siklus II ini terdiri dari kegiatan pendahuluan, inti, dan penutup.

Pada kegiatan pendahuluan ini hal-hal yang dilakukan adalah kelas dibuka dengan salam, menanyakan kabar, dan guru mengecek kehadiran peserta didik. Peserta didik dan guru berdoa yang dipimpin oleh salah satu peserta didik. Peserta didik bersama guru mengkondisikan kelas kemudian menyanyikan lagu Indonesia raya. Setelah itu guru memberikan penjelasan tentang sikap disiplin dan tanggung jawab yang akan dikembangkan dalam pembelajaran.

Pada kegiatan inti ini dilakukan dengan beberapa tahap yaitu peserta dibagi ke dalam kelompok-kelompok (4 kelompok) yang terdiri atas 4 anggota, salah satu anggota berisikan 3 orang. Kemudian setiap kelompok diberi kertas plano atau flip cart. Kemudian setiap kelompok ditentukan topik atau tema pembelajaran yang akan dibahasnya. Tema yang akan dibagikan ialah seputar perbedaan jensis tanaman berdasarkan karakteristik bentang alam. Setiap kelompok mendiskusikan apa yang ia ambil dari materi tersebut. Hasil kerja kelompok ditempel didinding. Masing-masing kelompok berputar mengamati hasil kerja kelompok lain dan menempeli dinding dengan daftar-daftar komentar. Salah satu wakil kelompok menjelaskan setiap apa yang ditanyakan oleh kelompok lain. Kelompok yang bertugas memberikan penjelasan pada pertemuan ini ialah oleh kelompok 1 dan 2 . Lalu peserta didik bersama guru melakukan koreksi secara bersama-sama. Lalu guru bersama peserta didik melakukan klarifikasi dan penyimpulan.

Pada kegiatan penutup ini, peserta didik bersama guru melakukan refleksi terhadap pembelajaran yang sudah berlangsung. Kemudian guru bersama peserta didik menyimpulkan hasil pembelajaran. Lalu peserta didik menyimak penjelasan guru tentang aktivitas pembelajaran pada pertemuan berikutnya. Tidak lupa pula guru memberikan motivasi tentang pentingnya sikap disiplin dan tanggung jawab. Setelah itu peserta didik diinstruksikan untuk menjaga kebersihan kelas. Dan terakhir kelas ditutup dengan do'a bersama yang dipimpin oleh salah satu peserta didik.

Pertemuan kedua siklus I dilaksanakan pada hari Selasa tanggal 26 Maret 2019 pada jam ke 1 dan 2 yang membahas materi tentang fungsi dan peran sumber daya alam dalam pembangunan 
nasional. Sama halnya pada pertemuan pertama siklus II ini terdiri dari kegiatan pendahuluan, inti, dan penutup.

Pada kegiatan pendahuluan ini hal-hal yang dilakukan adalah kelas dibuka dengan salam, menanyakan kabar, dan guru mengecek kehadiran peserta didik. Peserta didik dan guru berdoa yang dipimpin oleh salah satu peserta didik. Peserta didik bersama guru mengkondisikan kelas kemudian menyanyikan lagu Indonesia raya. Setelah itu guru memberikan penjelasan tentang sikap disiplin dan tanggung jawab yang akan dikembangkan dalam pembelajaran. Guru memberitahukan di akhir pembelajaran akan diberikan ulangan harian.

Pada kegiatan inti ini dilakukan dengan beberapa tahap yaitu peserta dibagi ke dalam kelompok-kelompok (4 kelompok) yang terdiri atas 4 anggota, salah satu anggota berisikan 3 orang. Kemudian setiap kelompok diberi kertas plano atau flip cart. Kemudian setiap kelompok ditentukan topik atau tema pembelajaran yang akan dibahasnya. Tema yang akan dibagikan ialah seputar perbedaan jensis tanaman berdasarkan karakteristik bentang alam. Setiap kelompok mendiskusikan apa yang ia ambil dari materi tersebut. Hasil kerja kelompok ditempel didinding. Masing-masing kelompok berputar mengamati hasil kerja kelompok lain dan menempeli dinding dengan daftar-daftar komentar. Salah satu wakil kelompok menjelaskan setiap apa yang ditanyakan oleh kelompok lain. Kelompok yang bertugas memberikan penjelasan pada pertemuan ini ialah oleh kelompok 3 dan 4 . Lalu peserta didik bersama guru melakukan koreksi secara bersama-sama. Lalu guru bersama peserta didik melakukan klarifikasi dan penyimpulan.

Pada kegiatan penutup ini, peserta didik bersama guru melakukan refleksi terhadap pembelajaran yang sudah berlangsung. Kemudian guru bersama peserta didik menyimpulkan hasil pembelajaran. Lalu peserta didik menyimak penjelasan guru tentang aktivitas pembelajaran pada pertemuan berikutnya. Tidak lupa pula guru memberikan motivasi tentang pentingnya sikap disiplin dan tanggung jawab. Setelah itu peserta didik diinstruksikan untuk menjaga kebersihan kelas. Dan terakhir kelas ditutup dengan do'a bersama yang dipimpin oleh salah satu peserta didik.

c. Observasi

Hasil belajar diperoleh dari lembar kerja peserta didik yang dilakukan pada setiap akhir siklus. Data yang diperoleh berupa angka mengenai hasil belajar yang diperoleh masing-masing peserta didik pada setiap siklus. Untuk lebih jelasnya hasil belajar peserta didik dapat dilihat pada tabel hasil belajar di bawah ini:

Tabel 2. Rekapitulasi Ketuntasan Belajar Peserta didik Siklus I

\begin{tabular}{|c|c|c|}
\hline No & Uraian & Hasil \\
\hline 1 & Jumlah Nilai & 1002 \\
\hline 2 & Rata-rata Nilai & 71.57 \\
\hline 3 & Peserta didik Tuntas & 12 \\
\hline 4 & Peserta didik Tidak Tuntas & 2 \\
\hline 5 & Persentase Peserta didik Tuntas & $86 \%$ \\
\hline
\end{tabular}




\section{Dari tabel di atas dapat dijelaskan bahwa setelah menerapkan model pembelajaran Gallery} Walk pada siklus II ini di peroleh rata - rata hasil belajar peserta didik yaitu 71,57 dengan jumlah peserta didik yang tuntas sebesar $86 \%$ (12 orang peserta didik) dan selebihnya $14 \%$ belum tuntas ( 2 orang peserta didik).

\section{d. Refleksi}

Refleksi dilakukan pada hari Jum'at tanggal 8 oktober 2021 pada pukul 11.00 sampai dengan 11.30 Wib. Berikut ini adalah hasil pengamatan oleh kolaborator yaitu Zulfahmi, S.Ag. terhadap proses pembelajaran dengan menggunakan model Gallery Walk. Berdasarkan hasil pengamatan kolaborator terhadap pelaksanaan proses pembelajaran melalui model Gallery Walk. Peserta didik sudah mengerti dengan metode yang diterapkan guru dalam proses pembelajaran hal ini dilihat dari hasil belajar peserta didik sudah mencapai keriteria yang di harapkan dengan tindakan pemberian reward/hadiah. maka dari itu penelitian ini tidak perlu di lanjutkan ke siklus berikutnya.

\section{Diskusi}

Dalam pembelajaran dengan model pembelajaran Gallery Walk ini peserta didik diarahkan menemukan konsep melalui kegiatan-kegiatan diskusi. Dalam pembelajaran, guru membimbing peserta didik berada disamping mereka yang membutuhkan bimbingan, membuat peserta didik merasa puas dan senang dan merasa diperhatikan sehingga peserta didik merasa bersemangat belajar. Pelaksanaan model Gallery Walk di kelas IV SDN 015/X Kuala Lagan telah memberikan dampak yang positif.

Hosnan (2014: 7) menyatakan bahwa belajar pada hakikatnya adalah proses interaksi terhadap semua yang ada di sekitar individu. Melaksanakan pengelolaan kelas dengan baik agar peserta didik termotivasi dalam mengikuti pembelajaran serta Memberikan pujian kepada peserta didik dapat meningkatkan hasil belajarnya karena termotivasi dalam pembelajaran. Hal ini sesuai dengan pendapat Sudjana (2004) bahwa hasil belajar peserta didik pada hakikatnya adalah perubahan tingkah laku sebagai hasil belajar dalam pengertian yang lebih luas mencakup bidang kognitif, afektif, dan psikomotorik. Berikut ini grafik peningkatan hasil belajar IPS peserta didik dari siklus I, dan siklus II. Besar peningkatannya yaitu $57 \%$, dan $86 \%$.

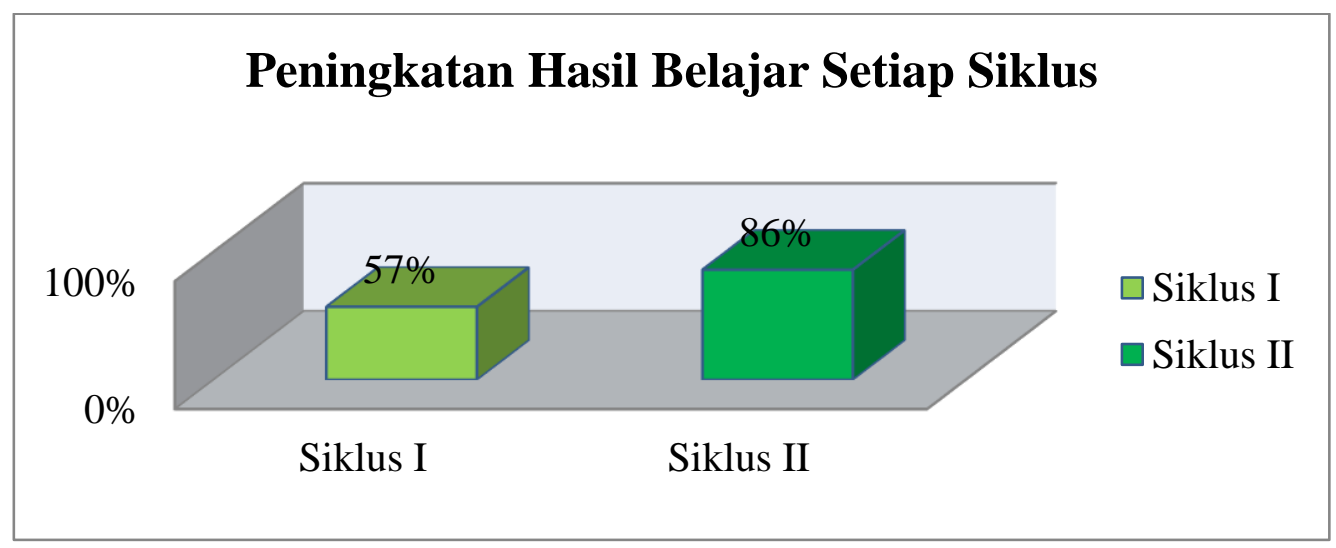




\section{KESIMPULAN}

Gambar 1. Peningkatan hasil belajar

Dari hasil kegiatan pembelajaran yang telah dilakukan selama dua siklus, dan berdasarkan seluruh pembahasan serta analisis yang telah dilakukan dapat disimpulkan bahwa pembelajaran dengan model pembelajaran Gallery Walk memiliki dampak positif dalam meningkatkan hasil belajar peserta didik yang ditandai dengan peningkatan ketuntasan belajar peserta didik dari siklus I, dan siklus II, masing-masing 57\% dan 86\% dengan tindakan pemberian reward/hadiah. Pada siklus II ketuntasan belajar peserta didik secara klasikal telah tercapai. Pembelajaran kooperatif tipe Gallery Walk mempunyai pengaruh positif, yaitu dapat meningkatkan hasil belajar peserta didik yang ditunjukan dengan rata-rata jawaban peserta didik yang menyatakan bahwa peserta didik tertarik dan berminat dengan model pembelajaran Gallery Walk sehingga mereka menjadi termotivasi untuk belajar.

Dari hasil penelitian yang diperoleh dari uraian sebelumnya agar proses belajar pembelajaran IPS lebih efektif dan lebih memberikan hasil yang optimal bagi peserta didik, maka disampaikan saran yaitu untuk melaksanakan model pembelajaran Gallery Walk memerlukan persiapan yang cukup matang, sehingga guru harus mempu menentukan atau memilih topik yang benar-benar bisa diterapkan dengan model pembelajaran Gallery Walk dalam proses belajar mengajar sehingga diperoleh hasil yang optimal. Dalam rangka meningkatkan prestasi belajar peserta didik, guru hendaknya lebih sering melatih peserta didik dengan berbagai model pembelajran, walau dalam taraf yang sederhana, dimana peserta didik nantinya dapat menemukan pengetahuan baru, memperoleh konsep dan keterampilan, sehingga peserta didik berhasil atau mampu memecahkan masalah-masalah yang dihadapinya. Untuk penelitian yang serupa hendaknya dilakukan perbaikan-perbaikan agar diperoleh hasil yang lebih baik.

\section{UCAPAN TERIMA KASIH}

Ucapan terima kasih sangat layak disampaikan untuk semua pihak yang telah membantu dalam pengerjaan artikel ini. Baik teman, dosen, kakak, dan yang lainnya. Artikel ini dapat dibuat karena adanya bantuan mereka. Semoga artikel ini dapat bermanfaaat untuk banyak pihak.

\section{REFERENSI}

Ahmad Kosasih Djahiri. 1996. Dasar-dasar Umum Metedologi dan Pelajaran Nilai dan Moral PVCT. Purwakarta IKIP.

Arikunto, Suharsimi.2005. ManajemenPenelitian. Jakarta: RinekaCipta.

Depdikbud. 1995. Kamus Besar BahasaIndonesia. Jakarta: Balai Pustaka.

Ghufron \& Risnawita. 2011. Teori-Teori Psikologi. Yogyakarta: Ar-Ruzz Madia

Hosnan. 2014. Pendekatan Saintifik dan Kontekstual dalam Pembelajaran Abad 21. Bogor: Ghalia Indonesia. 
Iskandar. 2009. Penelitian Tindakan Kelas. Jakarta: Gaung Persada Press.

Ismail, SM. 2008. Strategi Pembelajaran Agama Islam Berbasis PAIKEM. Semarang: Raisail.

Pribadi, Benny A. 2011. Metode Desain Sistem Pembelajaran. Jakarta: Dian Rakyat.

Riyanto, Yatim. 2012. Paradigma Baru Pembelajaran: Sebagai Referensi Bagi Guru/Pendidik Dalam Implementasi Pembelajaran Yang Efektif dan Berkualitas. Jakarta: Prenada Media Group.

Sanjaya, Wina.2013. Strategi Pembelajaran Berorientasi Standar Proses Pendidikan.Jakarta: Kencana. Silberman, Melvin L. 2005. Active Learning Cara Bealajar Peserta didik Aktif. Bandung: Nuansa.

Slameto. 2010. Belajar dan Faktor-Faktor Yang Mempengaruhinya. Jakarta: Rineka Cipta.

Sudjana, Nana. 2004. Dasar-dasar Proses Belajar Mengajar. Bandung: Sinar Baru Algensido Offset.

Wena, Made. 2010. Strategi Pembelajaran Inovatif Kontemporer: Suatu Tinjauan Konseptual Operasional. Jakarta: Bumi Akasara.

Yamin, Martinis dan Maisah. 2010. Standarisasi Kinerja Guru. Jakarta: Persada Press. 